\title{
HISTORICAL INFLUENCE OF MAN ON THE VEGETATION RECORD IN THE PRÁŠILSKÉ LAKE SEDIMENTS (BOHEMIAN FOREST, CZECH REPUBLIC)
}

\section{Eva Břízová}

CZECH GEOLOGICAL SURVEY, KLÁROV 3/131, 11821 PRAHA 1, CZECH REPUBLIC; e-mail: eva.brizova@geology.cz

\begin{abstract}
The Prášilské Lake is the glacial lake in the Bohemian Forest (Šumava Mts) located on the Czech side in the elevation of 1,079 $\mathrm{m}$ above sea level. The lake area is $4 \mathrm{ha}$, the maximal depth is $15.5 \mathrm{~m}$. The lake catchment area is situated in the sub-alpine zone. The studied area has never been the object of forest or agricultural farming in the history because of its inaccessibility. The sediment dating was carried out by means of lead isotope ${ }^{210} \mathrm{~Pb}$. The oldest layer established by this isotope in the Prášilské Lake was in the depth of $0.47 \mathrm{~m}$. This dating was used for the deepest layer of sediment and its age was dated to the year of 1843 (depth $0.11 \mathrm{~m}$ ) and a base of this profile to the medieval age (depth $0.47 \mathrm{~m}$ ), which corresponds to about the 12th-13th century A.D. The analysed profile $(0-0.47 \mathrm{~m})$ can be divided into the local pollen assemblage zones PRI-1 (depth 0.37-0.47 m), PRI-2 (depth 0.25-0.37 m), PRI-3 (depth 0.120.25 m), PRI-4 (depth 0.06-0.12 m), PRI-5 (depth 0.02-0.06 m), PRI-6 (depth 0-0.02 m). On the basis of dating by the ${ }^{210} \mathrm{~Pb}$ method the age of sediment $(0-0.11 \mathrm{~m})$ is established into the range of 1843 to 1994. It is noticeable in the pollen spectrum that it concerns a locality situated already above the forest border, the pollen curves of stratigraphical important taxons (mainly woody species) do not change markedly. The rich woody component is formed mainly by pollen grains of Picea and Fagus. The herbaceous component (NAP) is very diverse; however, in a general way the pollen grains of woody species (AP) predominate due to the above mentioned deciduous forests. A representation of the herbaceous component (NAP) is very varied as far as species are concerned, human influence is very visible here (e.g. occurrence of cereals Cerealia, Zea mays, Fagopyrum-type, weed: Centaurea cyanus, Agrostemma githago etc.). The dating of this part also corresponds to the results of the pollen analysis. Of the plants producing spores the findings of lesser clubmoss (Selaginella-type cf. Selaginella selaginoides) and water plant quillwort (Isoëtes), whose nearest contemporary place of the finding in our territory is in the Černé and Plešné Lake and Wielki Staw (the Giant Mts), were quite interesting. The most of spores were recorded at the family Polypodiaceae and green alga Botryococcus, which indicate cold and humid conditions of the occurrence.
\end{abstract}

Key words: palynology, Holocene, Prášilské Lake, Bohemian Forest, Czech Republic, biostratigraphy, ${ }^{210} \mathrm{~Pb}$ dating, human impact

The Bohemian/Bavarian Forest (Šumava Mts) is formed by igneous and metamorphic rocks, therefore it is ranked among the oldest mountains in the Central Europe (Babůrek 1996, 2001, Babůrek and Pošmourný 2001, Babůrek et al. 2006a, 2006b). After the last glacial period recession the development of glacial lakes and extensive peat bogs in the Bohemian Forest began (Břízová et al. 2006, Břízová and Pazdur 2007, Jankovská 2006, Mentlík et al. 2010, Spitzer and Bufková 2008), their sediments preserve the traces of extinct life.

Lately the researches of glacial lake sediments have been conducted here. At the same time the lakes, which are silted today, have been found (e.g.
Stará Jímka - Pod Poledníkem, Mentlík et al. 2010, a small lake near the Černé Lake, Vočadlová et al. 2007). In the past the main attention was paid to the Černé Lake (Reissinger 1930, 1933; Břízová 1991a, b, 1993, 1996; Řeháková 1991) and informative to the Čertovo Lake (Veselý et al. 1993, Veselý 1994; Břízová 1996). Recently the detailed research was also carried out in the Plešné Lake (Jankovská 2006). Limnic sediments of the Černé, Čertovo and Plešné Lakes and the Stará Jímka [former lake] Jankovská 2006, Mentlík et al. 2010), which are of the Quaternary age, are about 5-6 $\mathrm{m}$ thick and their origin is dated to the Late Glacial (I-III, Firbas 1949, 1952). 
The current state of all 5 existing the Bohemian Forest lakes (Černé, Čertovo, Plešné, Prášilské, Laka) is decisively determined by anthropogenic pollution borne by atmosphere. Moreover the Černé and Plešné Lakes are (Jankovská 2006, Bř́izová 2007a, b, c, d, 2011) the significant localities of incidence of rare quillwort (Isoëtes L. - I. lacustris and I. echinospora).

Geological, geomorphological, climatic and palaeobotanical findings in the former lake and in the current raised bog of Stará jímka - Pod Poledníkem in the altitude of $1,115 \mathrm{~m}$ above sea level confirmed a hypothesis of glacial lake, later silted (Babůrek et al. 2006, Břízová 2004, Břízová and Havlíček 2004, Břízová, Havlíček and Mentlík 2006, Mentlík et al. 2010). Glaciations in the broader surroundings of the Prášilské Lake finished probably $13,000-14,000$ years ago, which is proved by AMS and conventional radiocarbon dating, pollen and palaeoalgological analysis of organic matter sampled from the limnic sediments. The assumed hypothesis of the Prášilské Lake and Stará Jímka origin is discussed in details in works of (Břízová and Mentlík 2005a, 2005b, Mentlík and Břízová 2005, Mentlík, Lisá and Břízová 2006).

The diatomaceous flora in the Černé Lake was studied by Řeháková (1991), who focused on findings of trophic state of the lake currently and in the past of its growth. Later the diatom flora was also studied in the Čertovo Lake (Veselý et al. 1993).

The limnological research of water ecosystems has been conducting since the end of the 19th century; in the nineties of the 20th century the Černé Lake was primarily investigated and the research gradually extended to the other lakes. Palaeolimnological researches of the Čertovo Lake were carried out by Veselý and his team (Veselý et al. 1993, Veselý 1994), the Plešné Lake was studied by a research team (Kopáček et al. 2006).

The thorough biostratigrapfical research of limnic sediments and peats is a basis for monitoring of the natural environment of the Bohemian Forest in the course of the Quaternary period and particularly the last ca 200 years of development of all ecosystems, which are more or less influenced by human and his interferences into the natural development of the landscape.

Organic sediments of peat bogs are in the territory of the Bohemian Forest very extensive in area and also in a number of humolite, they are of con- siderable and very significant stratigraphical and palaeogeographical importance. Lately their research was improved mostly due to the detailed palynological investigation (detailed data see Bŕízová 2012). At the same time the pollen monitoring of the current vegetation has been carrying on since 1966 in the Bohemian Forest (SvitavskáSvobodová et al. 2007).

\section{STUDY AREA}

The Prášilské Lake $\left(49^{\circ} 05 \mathrm{~N}, 13^{\circ} 24 \mathrm{E}\right)$ is one of 8 glacial lakes in the territory of the Bohemian/ Bavarian Forest (the Bohemian Forest: Černé, Čertovo, Plešné, Prášilské, Laka) and the Bavarian Forest (Velké Javorské, Malé Javorské, Rachel). It is situated southeast of the village of Prášily in the central part of the Bohemian Forest in the altitude of $1,079 \mathrm{~m}$ (Figs. 1, 2). The area of lake is $4 \mathrm{ha}$, maximal depth $15.5 \mathrm{~m}$, the area of catchment about 52 ha. The lake is of Pleistocene age (Břízová 2009) having the best preserved moraine of all the Bohemian Forest lakes (Mentlík 2002, 2003, Mentlík et al. 2010).

During the geological, geomorphological and palaeoecological study of the territory of the sheet 1 : 25000 Srní (22-333) important types of sediments were studied and mapped and also their glacial development was verified. Both nearby

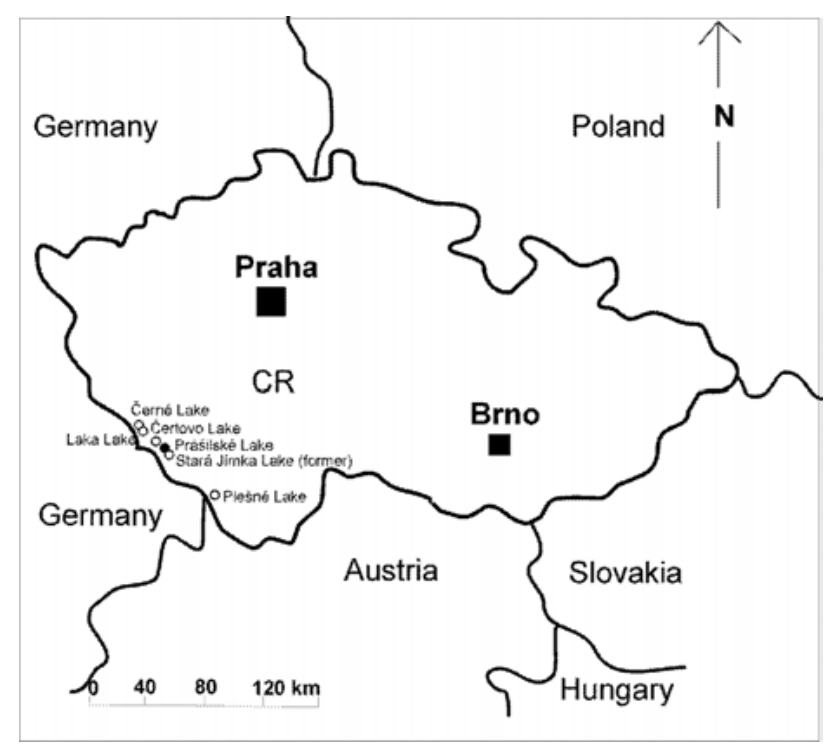

Fig. 1. The map of location of the Prášilské Lake (Bohemian Forest, Czech Republic). 


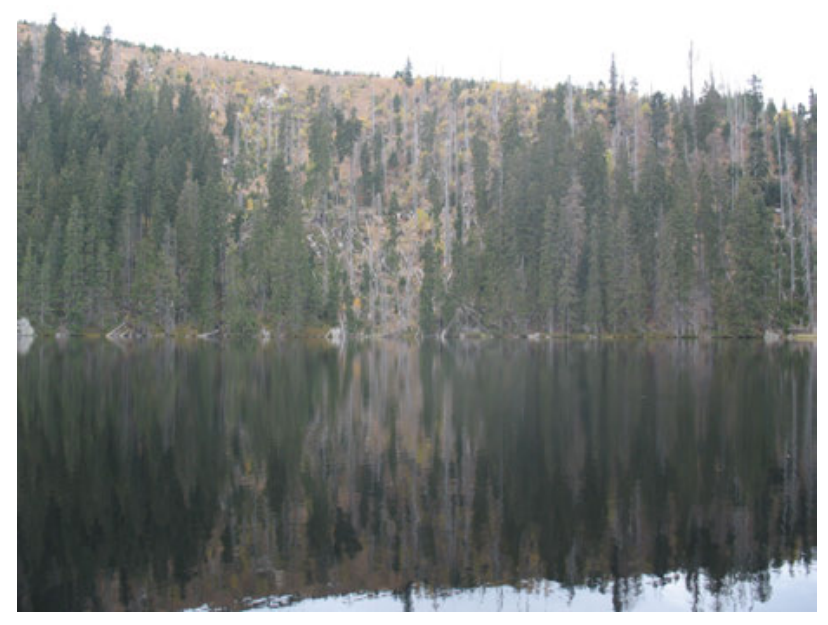

Fig. 2. Prášilské Lake (Bohemian Forest, Czech Republic). Photo E. Břizová.

lakes Prášilské and Stará jímka are of glacial origin. They are located near the village of Prášily east under Poledník (1,315 m a. s. 1.), Stará jímka is about $1500 \mathrm{~m}$ north of the Prášilské Lake. Both localities are in the valley of the Jezerní brook. Their Quaternary geological age starts in the Late Glacial $(15,000$ - 10,250 years BP) and continues in the course of the whole Holocene $(10,250$ - recent). The only difference is that the Prášilské Lake has been preserved up to now, Stará Jímka has silted itself in the course of the Holocene and a raised bog created in the place of lake.

\section{METHODOLOGY}

Pollen analysis was the basic method to reconstruct the past vegetation conditions during individual time stages of the Upper Holocene (Břízová et al. 2012, Novák et al. 2008). The vegetation is visually the most distinct component in a landscape, and its composition is the result of both abiotic and biotic factors. If we know the composition of vegetation, we can make deductions concerning, e. g. climate, pedology, geomorphology, and even the time of human colonisation of the studied region and the scope and quality of human activities.

Within the grant project (GA ČR No. 205/96/ 0933, Hruška et al. 1999) 0.47 m thick upper part of profile of organic sediments of the Prášilské Lake was palynologically evaluated for comparison with other methods determining humolite age and conditions of its origin (Novák et al. 2008). The sampling was carried out from the depth of $15 \mathrm{~m}$ into the special cylinder $0.06 \mathrm{~m}$ in diameter. Lithologically it is humic organic limnic sediment (upper $0.17 \mathrm{~m}$ dark brown to black, the rest of sediment brown) with noticeable clayey layers in the depth of 0.01-0.015 m, 0.10-0.12 $\mathrm{m}$ and 0.19-0.21 m. 31 samples with sampling by $0.01 \mathrm{~m}$ to $0.15 \mathrm{~m}$ and the rest of profile by $0.02 \mathrm{~m}$ was palynologically analyzed.

Laboratory treatment: decomposition of inorganic component was carried out by maceration in HF for ca 24 hours (Overbeck 1958, Faegri et al. 1964). An organic part, mainly cellulose, was removed by Erdtman acetolysis (Erdtman 1943, 1954); gained sporomorph were preserved in a mixture of ethylalcohol, glycerine and distilled water.

Microscopic treatment: calculation of individual objects was carried on the cover glass at the size of $22 \times 22 \mathrm{~mm}$; for statistical evaluation an amount of AP above 500 pollen grains was taken with exception of several samples, where their number was smaller. Real numbers of palynomorphs (see Table $1, \mathrm{AP}+\mathrm{NAP}=100 \%$,) after percent calculation were the basis for construction of a pollen diagram in the program POLPAL (Nalepka and Walanus 2003, Walanus and Nalepka 1999, 2010). Except pollen grains and spores a number of plant tissues and microscopic animal remains were found out in the microscopic biological preparations.

Dating of profiles of limnic sediments was carried out by means of residual activities of atmogenous ${ }^{210} \mathrm{~Pb}$ in layers $0.01-0.02 \mathrm{~m}$ thick. Methodology introduced in CR within the project GAČR (205/96/0370, Adamová and Novák 1998) was used for dating in CGS laboratories in Prague and in the Institute of Nuclear Research in Řež.

Relative dating of the pollen spectrum was carried out according to its composition. At reconstruction of vegetation development the classification according to Firbas (1949, 1952), Mangerud et al. 1974, Nalepka and Walanus (2003, Walanus and Nalepka 2010) and Břízová and Juřičková (2011) was used. Taxonomic classification of found pollen grains and spores is carried out according to the Key to flora of the Czech Republic (Kubát et al. 2002) and according to Beug (2004). 


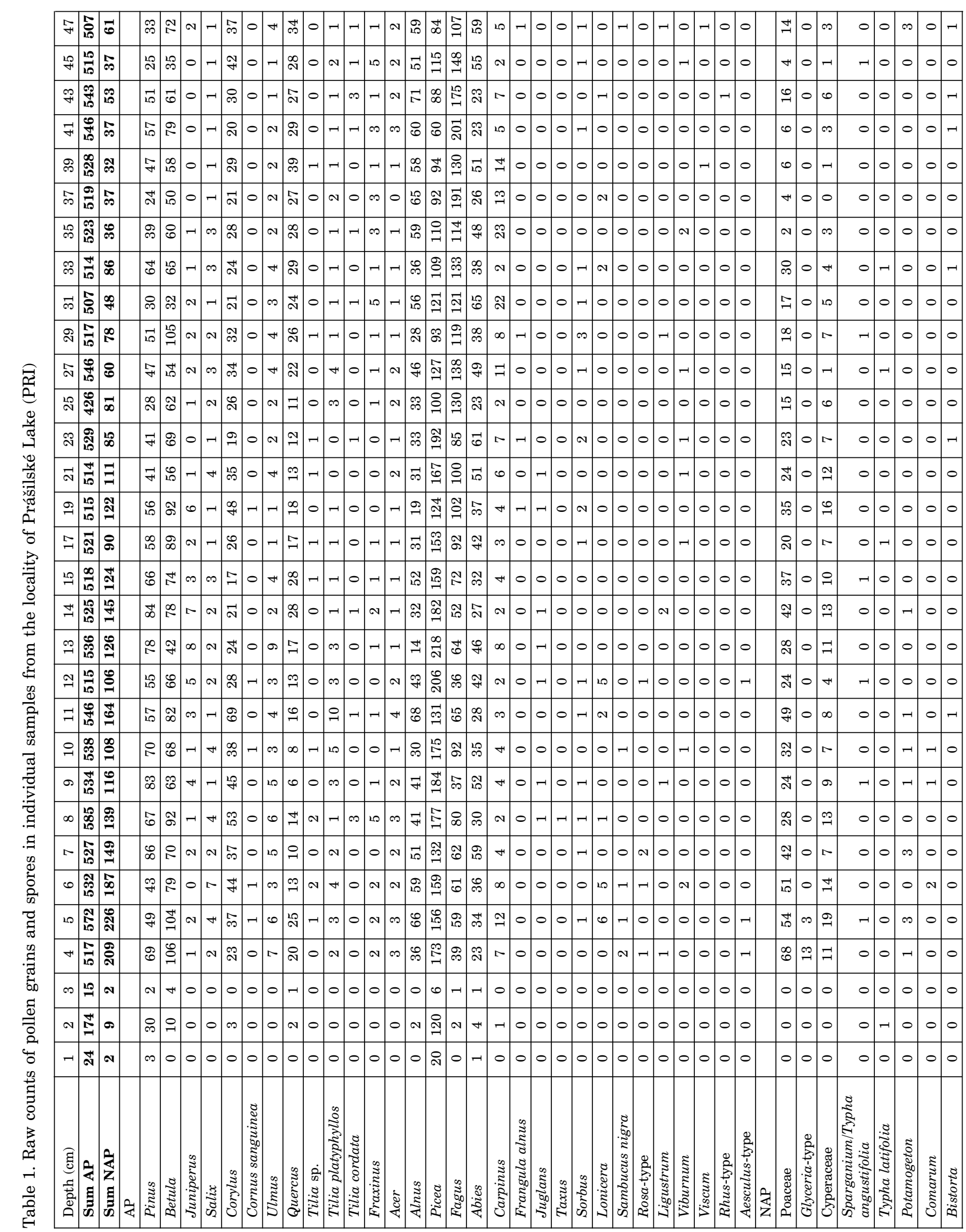




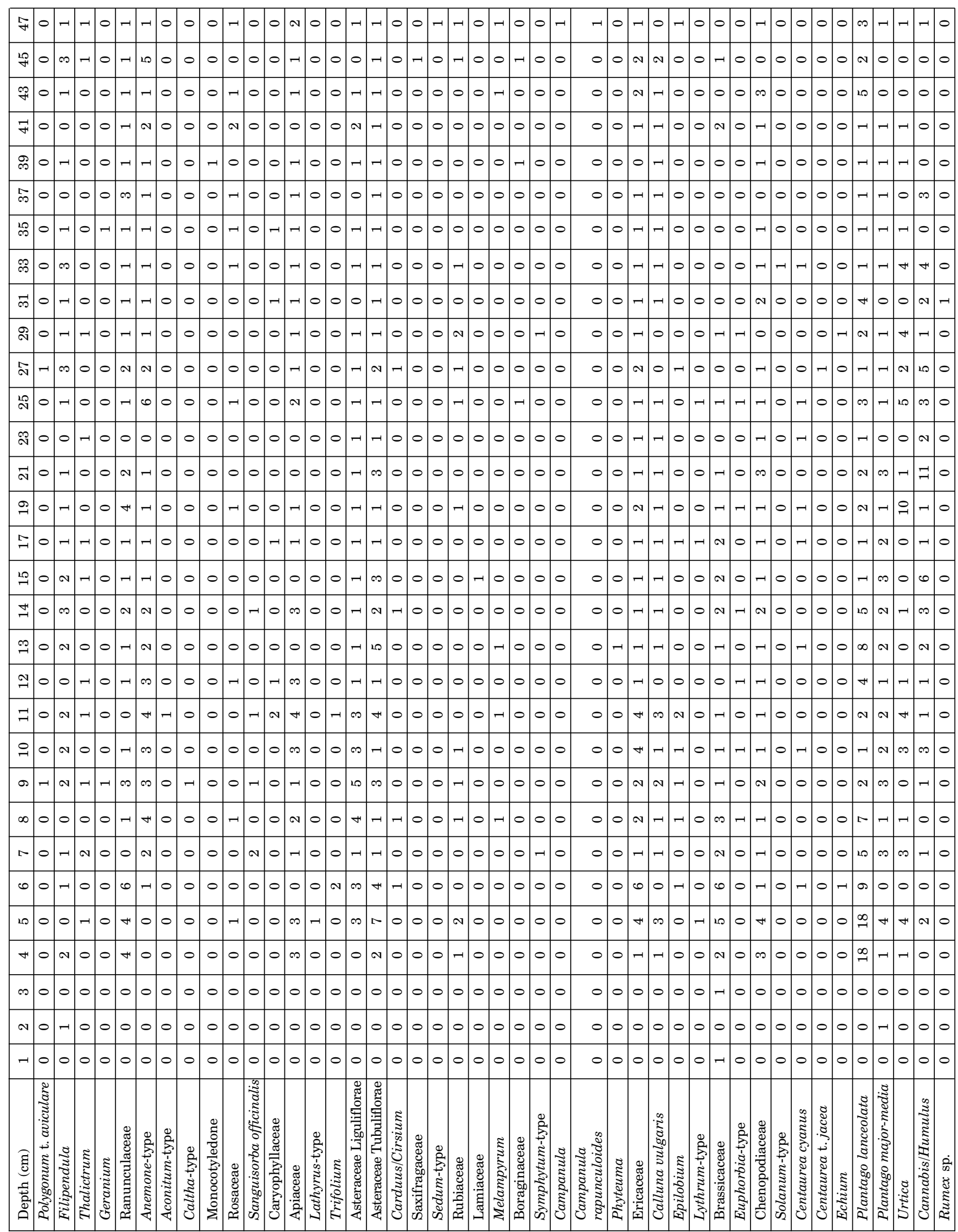




\begin{tabular}{|c|c|c|c|c|c|c|c|c|c|c|c|c|c|c|c|c|c|c|c|c|c|c|c|c|c|c|c|c|c|c|c|c|c|}
\hline & & -1 & & & & 010 & & 0 & $0 \stackrel{\sim}{\mathcal{N}}$ & & -1 & $\neg$ & 0 & & -10 & & & & & & & & & $\stackrel{\sim}{\circ}$ & 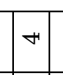 & & 0 & & & & 0. & -10 & \\
\hline L & & 4 & & 0 & 00 & 010 & & 0 & 0 O & & & -1 & 0 & 0. & 10 & 0 & ๙ & 0 & 0. & 10 & 0 & 0 & $\rightarrow$ & $\infty$ & $\sharp$ & & 0 & & 0 & 0 & 。 & -0 & \\
\hline ঞ & & | * & & 0 & 00 & 0 & 0 & 0 & 0.0 & & & -1 & 0 & 0 . & $-1-$ & 10 & \begin{tabular}{|c|c|} 
\\
0 \\
-1
\end{tabular} & 0 & 0.4 & 00 & -1 & -1 & 7 & 20 & $\stackrel{\infty}{\sim}$ & & -7 & 20 - & -1 & 0 & 0.0 & 00 & \\
\hline$F$ & & $4 \infty$ & 0 & 0 . & -10 & 00 & & 0 & 0.0 & 0 & & 0 & 0 & 0 . & -17 & 10 & 익 & 0 & 0 - & +10 & 0 & $\infty$ & $\rightarrow$ & 20 & ib & & 40 & & 0 & & 0. & 70 & \\
\hline ది & -10 & P & & 0. & $\rightarrow 0$ & 010 & 0 & 0 & $0 \mid \infty$ & $\infty$ & & 0 & 0 & 0 & 00 & 10 & $\infty$ & 0 & 0. & 10 & -1 & ๙ & 0 & $\infty$ & 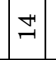 & & 0 & & -1 & & - & -10 & \\
\hline m. & 0 & | 10 & & -7 & 00 & 00 & 0 & 0 & $0=$ & & & 0 & 0 & 0 & 00 & 10 & 다 & 0 & 0. & $m 0$ & 0 & ๙ & 0 & จ & $\exists$ & & 0 & 10 & 0 & & 0. & -10 & \\
\hline 내 & 0 & 4 & & 0 & 0. & 10 & 0 & 0 & $0 \stackrel{2}{0}$ & & & N & 0 & 0 & 00 & 0 & (i) & 0 & 0 . & 10 & 0 & 0 & -1 & -1 & $\infty$ & & 0 & + & 0 & & 01 & -10 & \\
\hline డొ & 0.0 & 0 & 0 & 0 . & $\rightarrow m$ & 0 & 0 & 0 & 0.10 & ० & 0 & -1 & $\rightarrow$ & 0 & 00 & 0 & 离 & 0 & 0. & 60 & 0 & 0 & -1 & 0 & 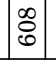 & & 0 & 이 & 0 & & 00 & 0.0 & \\
\hline ले & & A & 0 & 0 & 01 & -10 & 0 & 0 & 0.10 & . & 0 & 0 & 0 & 0 & 00 & 0 & $\infty$ & 0 & 01 & -10 & 0 & 0 & $\sim$ & $\infty$ & 墨 & & 0 & 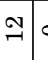 & 0 & & 0. & -10 & \\
\hline ลิ & & $\infty$ & 0 & 0 & $\sim \propto$ & $0-$ & $\rightarrow$ & 0 & 0.9 & $\rightarrow$ & 7 & -1 & -7 & 0 & $0-$ & 10 & 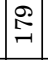 & 0 & 0.0 & 0 & 0 & $\infty$ & 0 & $\stackrel{20}{\sim}$ & $\begin{array}{l}\infty \\
\infty \\
\infty \\
\infty\end{array}$ & & 0 & & 0 & & $\circ 0$ & 0.0 & \\
\hline ล & & م & 0 & $\rightarrow$ & 0 . & $+\infty$ & 0 & 0 & 0 & & 0 & $\rightarrow$ & 0 & 0 & $0-1$ & 10 & $\mid \begin{array}{l}\infty \\
\stackrel{2}{-} \\
-1\end{array}$ & 0 & 0. & 10 & 10 & 0 & 0 & 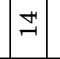 & $\stackrel{8}{\rightarrow}$ & & 0 & & 0 & & 00 & 0.1 & \\
\hline เి & & م & 0 & -1 & +0 & 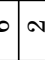 & 0 & 0 & 0.10 & & 0 & -1 & 0 & 0 & 00 & 10 & \begin{tabular}{|l|l|}
\multirow{2}{*}{} \\
\end{tabular} & 0 & -10 & $m 0$ & 10 & -1 & 0 & $\infty$ & if & & 0 & & 0 & & 00 & 0.0 & \\
\hline ๙ू & & 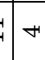 & & 0 & & $+\nabla$ & 0 & 0 & $0 \mid \vec{\sigma}$ & & 0 & 0 & 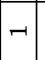 & 0 & 00 & 0 & 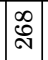 & 0 & $0 \%$ & $=0$ & 0 & $\rightarrow$ & $\rightarrow$ & $\sim$ & $\underset{H}{*}$ & & 0 & $\infty$ & 0 & & 0.0 & 0 & \\
\hline $\overrightarrow{\widetilde{N}}$ & & 4 & & 0 & N & 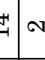 & 0 & 0 & $0 \cong$ & & 0 & -1 & -1 & 0 & 00 & 10 & ๙ָ๊ & 0 & 0.0 & $\infty$ & 10 & 0 & 0 & 0 & $\begin{array}{l}0 \\
+1 \\
-1\end{array}$ & & 0 & $\sigma$ & 0 & & 00 & 0.0 & \\
\hline$\stackrel{9}{]}$ & -10 & - & & $\rightarrow$ & 0 I & $y \infty$ & 0 & 0 & $0=$ & & -1 & 0 & 0 & 0 & $0-$ & 10 & 路 & 0 & 0. & 10 & 10 & -1 & 0 & 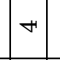 & 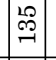 & & 0 & $\infty$ & 0 & & $\circ 0$ & 0.0 & \\
\hline 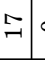 & $D=$ & -1 & -7 & 0 & $\sim \subseteq$ & 010 & 0 & 0 & 0.0 & ०) & , & 0 & -7 & 0 & 00 & 10 & 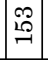 & 0 & 0. & 10 & 0 & 0 & 0 & 20 & ळ & & 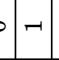 & $\sigma 0$ & 0 & & 0. & -10 & \\
\hline$\stackrel{2}{-10}$ & & o & 0 & 0 & $\infty$ & $\pm \infty$ & $\rightarrow$ & 0 & $0=$ & $\Rightarrow$ & -1 & 0 & 0 & 0 & 00 & 0 & 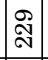 & $\rightarrow$ & 0.0 & 0 - 10 & 0 & -1 & 0 & $\exists$ & $\infty$ & & 0 & $\rightarrow$ & 0 & & $\circ$ & -10 & \\
\hline \pm & & o & & $\curvearrowright$ & $\infty$ & $=\sigma$ & 0 & -1 & \begin{tabular}{l|l}
0 & $\infty$
\end{tabular} & 0 & 0 & ๙ & 0 & 0 & 01 & 10 & \begin{tabular}{|c|c|} 
\\
0 \\
\end{tabular} & 0 & 0. & 00 & 0 & $\triangle$ & $\sim$ & 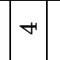 & $\stackrel{2}{\rightarrow}$ & & 0 & ब. & 0 & & 0.0 & $\sim 0$ & \\
\hline$\stackrel{\sim}{-1}$ & & A & & 0 . & $\# \sigma$ & $\Rightarrow 1$ & 0 & 0 & 00 & & $\circ$ & 0 & 0 & 0. & 70 & & $\mid \begin{array}{ll}\vec{b} \\
口\end{array}$ & 0 & 0. & $N$ & 10 & 0 & -1 & 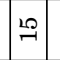 & ล & & -10 & $\infty$ & & & 00 & 0.0 & \\
\hline$\underset{7}{\mp}$ & $\exists-$ & 4 & & 0 & $ه$. & 0 & 0 & 0 & 09 & $\rightarrow$ & $\infty$ & 0 & 0 & 0 & ๙ & -1 & $\mid \begin{array}{l}0 \\
0 \\
0 \\
m\end{array}$ & 0 & 0. & -10 & 0 & $\rightarrow$ & 0 & $\infty$ & 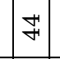 & & 0 & $\infty$ & 0 & & 0 & 00 & \\
\hline 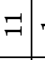 & $-r$ & 10 & 0 & $\rightarrow$ & 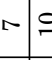 & $=10$ & 0 & 0 & 0 : & i & $\sim$ & $\rightarrow$ & 0 & 0. & 70 & 10 & \begin{tabular}{|l} 
\\
$\vdots$ \\
0
\end{tabular} & 0 & -1 & 0 & 10 & $\rightarrow$ & 0 & $\rightarrow$ & $\therefore$ & & 0 & $\infty$ & 0 & & 0. & -10 & \\
\hline 이 & & 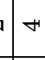 & & 0 & 2026 & - & 0 & 0 & $0 \stackrel{9}{\circ}$ & $\theta$ & 0 & $\neg$ & 0 & 0 & 00 & 10 & 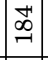 & 0 & 0 & 0 & 10 & 0 & 0 & $\sim$ & $\stackrel{8}{0}$ & & 0 & 0 & 0 & & 0 & -10 & \\
\hline$\sigma$ & & 10 & & $\rightarrow$ & $\rightarrow \infty$ & $\circ \mid \sim$ & 0 & 0 & 01 & & -1 & 0 & 0 & 0 & × & 10 & 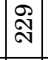 & 0 & -10 & 00 & 10 & $\infty$ & 0 & 0 & $\ddot{B}$ & & 0 & & 0 & & 0 & 0.0 & \\
\hline$\infty$ & ה ד ס & 40 & & $\rightarrow$ & $-1 \propto$ & 01 & 0 & 0 & $00_{\pi}$ & & 0 & $\rightarrow$ & 0 & 0 . & 70 & 0 & 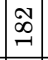 & $\neg$ & 0 & 0 & 10 & 0 & 0 & 0 & $\stackrel{\infty}{+}$ & 0 & 0 & 100 & -1 & & 0 & 00 & \\
\hline 5 & $\neq \infty$ & o & 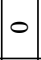 & 0 & $\infty \tau$ & $\begin{array}{lll}0 & 0\end{array}$ & 0 & 0 & $0 \approx$ & S & 0 & 0 & 0 & 0 . & -10 & 0 & 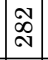 & 0 & 0 & 0 & 10 & 0 & 0 & $\stackrel{\circ}{\infty}$ & $\infty$ & & 0 & 0. & 0 & & - & 00 & \\
\hline 0 & \pm 0 & 10 & & 0 & $0 \%$ & $\theta \pm$ & 0 & 0 & $\sim$ จ & & -1 & 0 & 0 & $\rightarrow$ & 00 & 0 & 孚 & 0 & 0 & 00 & 10 & 0 & 0 & 0 & 跴 & & $p-1$ & 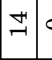 & 0 & & 0. & -10 & \\
\hline 20 & & $\infty$ & 0 & 0 & 01 & 19 & -1 & 0 & 0 ล & & 0 & 0 & 0 & 0 & 00 & 0 & $\exists$ & 0 & 0 & 0 & 10 & 0 & 0 & + & ๙ & 0 & $p-1$ & & 0 & & 0 & 00 & \\
\hline F & & o & & $\rightarrow$ & $\sigma \neq$ & 40 & 0 & 0 & $\rightarrow$ ล & & 0 & 7 & 0 & 0 & 00 & 00 & + & 0 & 0 & 00 & 0 & 0 & 0 & -7 & $\infty$ & & 0 & & -1 & & 0 & 00 & \\
\hline$\infty$ & & - & & 0 & 00 & 0 & 0 & & 0.0 & & 0 & 0 & 0 & 0 & 00 & 0 & 0 & 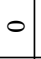 & & 0 & 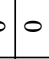 & 0 & 0 & 0 & $\neg$ & 0 & 0 & 0 & 0 & & 0 & 0.0 & \\
\hline ه & & 10 & & 0 & 00 & 0 & 0 & 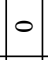 & 0.0 & 。) & -1 & 0 & 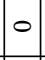 & 0 & 00 & 0 & 10 & 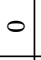 & 6 & 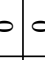 & 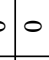 & 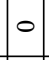 & 0 & 0 & 0 & $\rightarrow$ & $-1-1$ & $\infty$ & 0 & & 。 & 0.0 & \\
\hline - & & 0 & & & 00 & 010 & 0 & & \begin{tabular}{l|l} 
& -1
\end{tabular} & & o & 0 & 0 & 0 & 00 & 0 & $\rightarrow$ & 0 & 0 & 0 & & 0 & 0 & 0 & 0 & 0 & 0 & 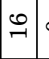 & 0 & & 0 & 0 & \\
\hline & & & & & 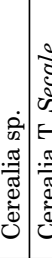 & 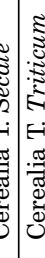 & & & 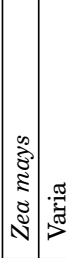 & 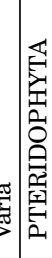 & & & & & 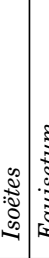 & 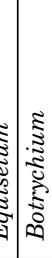 & & 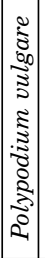 & & 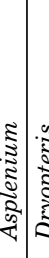 & Eี & & & & 竎 & 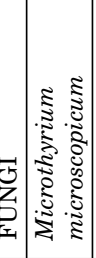 & & & & 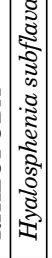 & & ֻัٌ & \\
\hline
\end{tabular}




\section{RESULTS AND DISCUSSION}

\section{POLLEN ANALYSIS RESULTS}

The collected profile of Prášilské Lake sediment covers the last ca 150-200 years and the medieval age of vegetation development. The pollen diagram (Fig. 3) distinguishes clearly the youngest Holocene section. Six local pollen assemblage zones (PRI-1-Xb to PRI-6-Xc) were distinguished in the pollen diagram.

On the basis of pollen analysis the taken profile of the limnic sediments of the Prášilské Lake (PRI) was classified into the younger phase of the Younger Subatlantic $\mathrm{Xb}$ and $\mathrm{Xc}$ according to Firbas $(1949,1952)$ and simultaneously was dated by the ${ }^{210} \mathrm{~Pb}$ method into the interval of $1843-1994$ (samples 31-1, thickness of dated sediment $0.47 \mathrm{~m}$, Hruška et al. 1999). The methodology was used on the Jezerní slat mire (Břízová 1996, Vile et al. 1995), Černé and Čertovo Lakes (Břízová 1996) and Rybárenská slat mire (Břízová 2012).

The vegetation development founded by pollen analysis divide the profile into $6 \mathrm{~L} \mathrm{PAZ} \mathrm{(Local} \mathrm{pol-}$ len assemblage zones):

\section{PAZ:}

\section{PRI-1-Xb: Fagus - Picea - Alnus}

depth $0.37-0.47 \mathrm{~m}$

The basis of analyzed profile was dated only palynologically to the period of the medieval age (12th-13th century A.D.), because the used method $\left({ }^{210} \mathrm{~Pb}\right)$ is not conclusive in a range of dating 200 years backward. Dating is possible only in the range of ca 19th to 21th century. A woody component (AP) on the profile basis ranges about $90 \%$. The beech (Fagus), fir (Abies), spruce (Picea), alder (Alnus) and birch (Betula) are mainly prevailing, substantially less it is pine (Pinus), hornbeam Carpinus), oak (Quercus). A shrubby layer is relatively varied (mainly birdseed Ligustrum, snowball Viburnum, type rose Rosa-type, alder buckthorn Frangula alnus)) and also tree whitebeam (Sorbus) appears. An herbaceous layer is rich in species, which indicated a gradual human presence. Grasses (Poaceae) and family Cyperaceae (sedge family) are mostly represented. Pasture is indicated by nettle (Urtica), sorel (Rumex t. acetosella). Cultivation of grain is only at the beginning (Cerealia sp.). Other anthropogenic indicators become more visible: Apiaceae, Asteraceae
Liguliflorae, Asteraceae Tubuliflorae, Brassicaceae, Chenopodiaceae, Plantago lanceolata (ribwort plantain), P. major-media (plantain bigger-medium), Artemisia (wormwood), Cannabis/Humulus (hemp/ hop). Wetland herbal types such as Potamogeton, Bistorta, Filipendula, Caltha-type are accompanied by a curve of spores Equisetum (horsetail) and Polypodiaceae and Sphagnum (peat moss). Other microremains of Rhizopoda, mainly genus of Nebella and Fungi Ascomycetes, Microthyrium microscopicum, Entophlyctis lobata, and Tilletia sphagni are also present.

A surprising finding was sporadic microspores of rare quillwort (Isoëtes) in the depth of 0.41-0.47 $\mathrm{m}$, which prove lacustrine biotope together with green algae of genus Botryococcus (see Fig. 3, Plate I). Currently the plants of quillwort have not been found in the Prášilské Lake, but it is more than probable that they grew here in the past (Břízová 2011).

The zone is stratigraphically classified into the younger phase of the Younger Subatlantic (Xb, Firbas 1949, 1952, Břízová and Juřičková 2011). The forest vegetation can be characterized by spruce-beech forests with climatic indicators, when a fir slightly appears, which is similar also in the following zone PRI-2-Xb, where is moreover human impact indicated mainly in the 13th century A.D. with the German colonisation.

\section{PRI-2-Xb: Fagus - Picea - Abies \\ - antropophytes - (Botryococcus) \\ depth $0.25-0.37 \mathrm{~m}$}

In this zone a woody component (AP) slightly falls down, but still it is the natural forest unaffected by human. Nevertheless, a beech, spruce, fir and birch are prevailing. Appearing juniper (Juniperus) accompanied by nettle (Urtica), sorel (Rumex t. acetosella) and some types of f. Ericaceae might indicate a pasture in the forest. A shrubby layer is markedly reduced due to the human farming. For the first time land farming penetrates through this zone also to the inaccessible parts of the Bohemian Forest. Human starts crop cultivation, mainly rye (Cerealia T. Secale), less wheat (T. Triticum) and oats (T. Avena). Crop cultivation is accompanied by weed Agrostemma githago and Centaurea cyanus. Other plants expanded mostly by human are Apiaceae, Asteraceae, Artemisia, Chenopodiaceae. Of plants producing spores the 


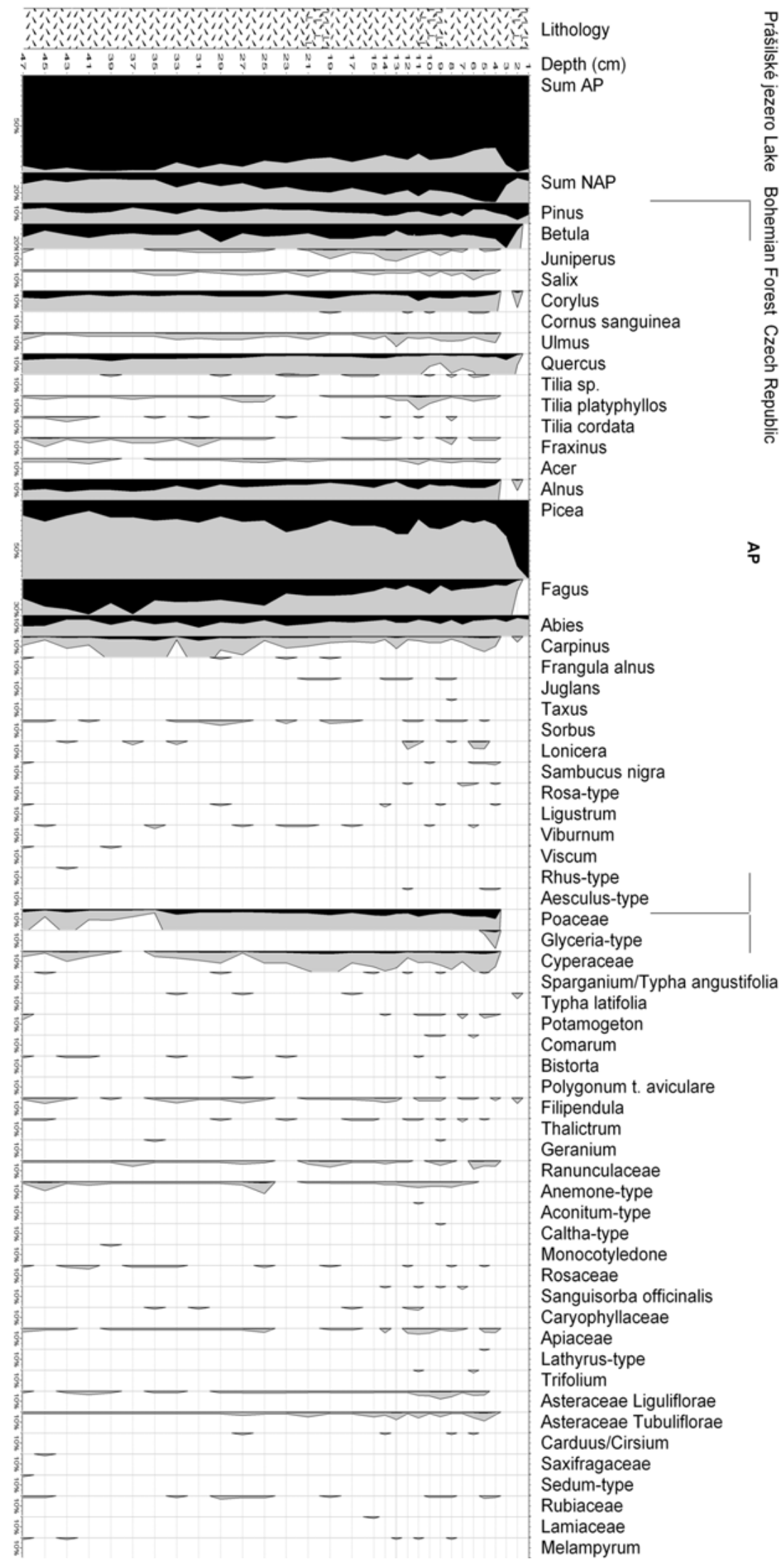




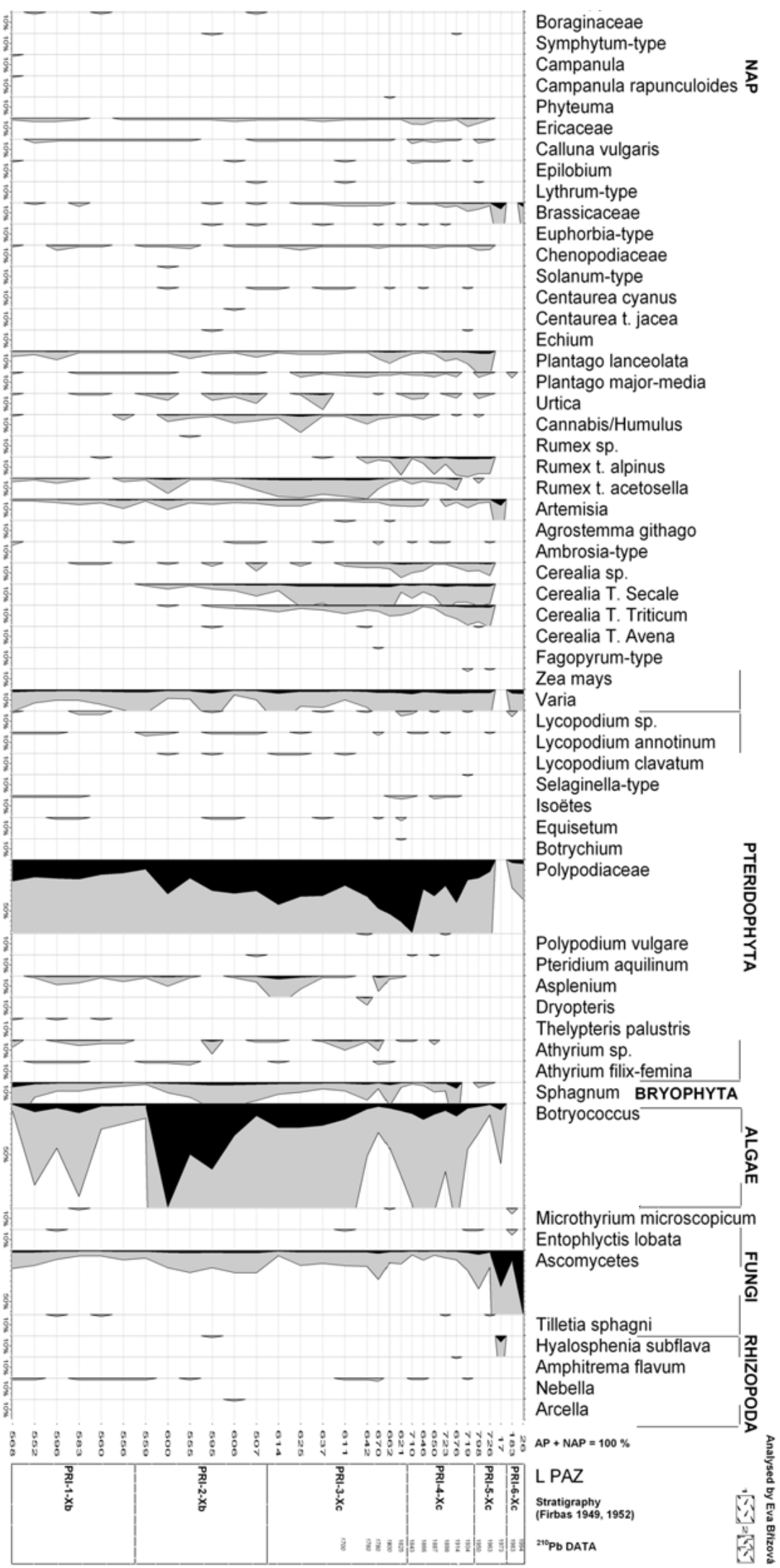


local wetland types such as horse-tail (Equisetum), Polypodiaceae, Asplenium, peat moss (Sphagnum) are still present. To a smaller extent some animal microremains of Rhizopoda and Fungi occur. The biggest representation belongs to coenobia green alga Botryococcus (Plate I) as in the lakes: Černé or Čejčské jezero Lake (Bř́izová 2009). They prove a lacustrine phase together with growing willows (Salix), alders (Alnus) and accompanying wetland types Sparganium/Typha angustifolia, Typha latifolia, Filipendula etc. in the lake surroundings.

\section{PRI-3-Xc: Picea - Fagus - Corylus}

- Juniperus - anthropophytes - (Polypodiaceae) depth $0.12-0.25 \mathrm{~m}$

In this zone a radical change in the forest character takes place, the ratio of beech and spruce turns in favour of spruce. It means that a character of the mixed forest changes to coniferous forests. Representation of woody components (AP) in the pollen spectrum slightly falls down. An amount of pollen grains of pine (Pinus) increases, fir (Abies) and hornbeam (Carpinus) stay at the same level (Fig. 3). Besides the named woody plants a woody layer becomes less varied. Similarly bushes and herbs, where cereals (Cerealia, $\mathrm{Fa}$ gopyrum-type), weed and types accompanying human prevail again, become less diverse. Wetland types (e.g. Cyperaceae) and types of meadow associations do not occur so much. At the beginning and the end of the zone the curves of spores of peat moss (Sphagnum) increased, what might be connected with water regime or directly with its presence in the lake. Mostly there are recorded spores of $\mathrm{f}$. Polypodiaceae. The microremains of Fungi Ascomycetes occurred continuously. Rhizopoda and other representatives of fauna occurred only sporadically. The change of forest character is recorded in the lacustrine sediments by forming a clay layer in the depth of ca 0.19-0.21 $\mathrm{m}$, which can be interpreted as an increased erosion in the lake catchment both due to the change of forest ecosystem (e.g. in 1778 the area of Prášilsko was affected by strong windstorm see Nožička 1957, Šantrůčková et al. 2010, Břízová 2012) and also by the human activity (deforestation in favour of fields and meadows). The year of 1790 is stated in the historical sources as rapid disappearance of spruce-fir-beech forests in the places of wood floating, which can be read out from the pollen diagram in a part of the pollen diagram in the zone PRI-2 and 3. Spores of quillwort (Isoëtes, see Fig. 3, Plate I) were also found in the depth of 0.11-0.13 m.

\section{PRI-4-Xc: Picea - Corylus - antropophytes}

? 1825-1934, depth 0.06-0.12 m

This zone has been already dated by the ${ }^{210} \mathrm{~Pb}$ method. Another clay layer in the depth of ca 0.10 $0.12 \mathrm{~m}$ is recorded here. A woody component behaves similarly as in the previous zone due to spruce (Picea) and pine (Pinus), less fir (Abies). Coniferous trees prevail and juniper still occurs (Juniperus). A shrubby layer is also poor; bushes probably disappear as a result of human presence and his farming on accessible places. An increased amount of spruce and pine pollens in the territory of the Bohemian Forest can be also supported by artificial planting of these woody plants. Farming is still the same as in the previous zone PRI-3. In the upper part a pollen grain of maize (Zea mays, see Plate I) was found in the depth of $0.06 \mathrm{~m}$ (dated to the year of 1934). Non-pollen objects show a steady drop of occurrence. Incidence of peat moss spores (Sphagnum) is comparable with the profile basis. A coherent curve of Polypodiaceae also falls slightly down.

At the boundary of zones in the depth of 0.11 , 0.12 and $0.13 \mathrm{~m}$ sporadic microremains of quillwort (Isoëtes, Plate I) were recorded again, which is on the basis of dating approximately at the turn of 18 th and 19th century (ca in the years of 1800 to 1825). In 1843 abundant clear-felled areas occurred in plenty of places in the Bohemian Forest, therefore in the following year a decree to expand cultivation of broadleaved trees by maple (Acer), ash tree (Fraxinus), beech (Fagus), and oak (Quercus) was issued, but in 1836 the beech (Fagus) planting was suppressed by spruce monocultures (Nožička 1957).

\section{PRI-5-Xc: Picea - Betula - Quercus - Poace- ae - antropophytes \\ 1934-1973, depth 0.02-0.06 m}

This zone is dated to the years of 1934 to 1973 . A sharp transition of plant ecosystems from the phase, when there existed farming in the Bohemian Forest. Into the phase, when resettlement of the border area took place Brrízová 2012) and the area was gradually overgrown by wild herbs and bushes. A pioneer birch (Betula) started to spread 
and also oak (Quercus) was rejuvenated, because it was not used so much by human and might have spread and been rejuvenated. Spruce and pine started to prevail, while other woody plants such as elm (Ulmus), linden (Tilia), maple (Acer), hazel (Corylus), alder (Alnus) and willow (Salix) gradually disappear from the pollen spectrum. In the depth of about $40 \mathrm{~mm}$ a maize grain (Zea mays) was found being dated to the year of 1963 . The extent, way and time of farming in the Bohemian Forest can be read out from the pollen spectrum as well as how 2 waves of resettlement in 1939 and 1945 were reflected in the vegetation composition. Up to the years of 1925-1942 the considerable farming impacts (mostly pollen grains of herbs and a shrubby layer indicate these activities) are evident. After the years of 1942-1990 these matters are gradually restrained and partially vanish.

\section{PRI-6-Xc: Picea - Pinus}

1973-1994, depth 0.00-0.02 m

In the years of 1984-1996 the forest in the lake catchment was little by little dying as a consequence of wind calamities and a subsequent bark beetle outbreak (Břízová 2012). An amount of pollen grains in this zone strikingly decreased. Renewing origin of clay layer in the depth of 0.01$0.015 \mathrm{~m}$ as well as the forest recession contributed to this phenomenon. A forest character in the lake catchment corresponds to the current vegetation conditions. These are spruce monocultures and it means the maximal spruce expansion in the course of whole profile. The human presence, i.e. his impact and farming does not appear in the spectrum. Of woody plants there is spruce (Picea), pine (Pinus), hazel (Corylus), fir (Abies), and hornbeam (Carpinus). Both an herbaceous layer and non-pollen objects (Polypodiaceae, Ascomycetes, Microthyrium microscopicum, Entophlyctis lobata) were very poor. In the depth of 0.07-0.09 m sporadic microspores of quillwort (Isoëtes) were found being dated to the turn of 19th and 20th century.

A woody component (AP) prevails in the whole profile over the herbaceous one (NAP). From time immemorial there have been vast forests in the Bohemian Forest, which is reflected in its name (Nožička 1957, Šantrůčková et al. 2010, Břízová 2012). In the last 300 years a pine expanded to the forests, where beech, spruce and fir were dominating.

In the pollen diagram this state becomes evident mostly at oak and linden, because the pollen production at other broadleaved trees is very small and without dating method is poorly recordable (maple, beech, etc.). The extent, way and time of farming in the Bohemian Forest can be read out from the pollen spectrum as well as how two waves of resettlement in 1939 and 1945 were reflected in the vegetation composition. Up to the years of 1925-1942 the considerable farming impacts are (mostly pollen grains of herbs and a shrubby layer indicate these activities) are evident. After the years of 1942-1990 these matters are gradually restrained and partially vanish.

\section{INTERPRETATION OF POLLEN ANALYSIS RESULTS}

Vegetation conditions found out by the pollen analysis and supported by ${ }^{210} \mathrm{~Pb}$ dating are similar as at earlier worked out peat and lake profiles in the area of the Bohemian Forest (Břízová 2011, 2012, Vile et al. 1995). At the beginning of the 19 th century an amount of pollen grains of woody species of natural forest gradually decreases, mostly beech (Fagus), fir (Abies), hornbeam (Carpinus), on the contrary spruce (Picea) and pine (Pinus) increase as a consequence of planting these woody species in the form of today monocultures. The steady forestation of the territory has been shown (see values of AP sum in the Table 1). An herbaceous component (NAP) is very low, but incredibly varied in species (see Fig. 3, Plate I). Its composition is affected by human activity mostly in the upper parts of the profile.

\section{CONCLUSION}

1. The lacustrine sediments of the Prášilské Lake $(0-4.7 \mathrm{~mm})$ are stratigraphically classified into the Subboreal period to the younger phase of the Younger Subatlantic (Xb-Xc, Firbas 1949, 1952, Mangerud et al. 1974, Walanus and Nalepka 2010, Břízová and Juřičková 2011). The age was found out by means of pollen analysis and dating by means of ${ }^{210} \mathrm{~Pb}$ isotope. The detailed segmentation of vegetation zones and their stratigraphical classification is stated in the Table 2. 
Folia vol. 46, No. 1-2, 2012

\section{Plate I.}

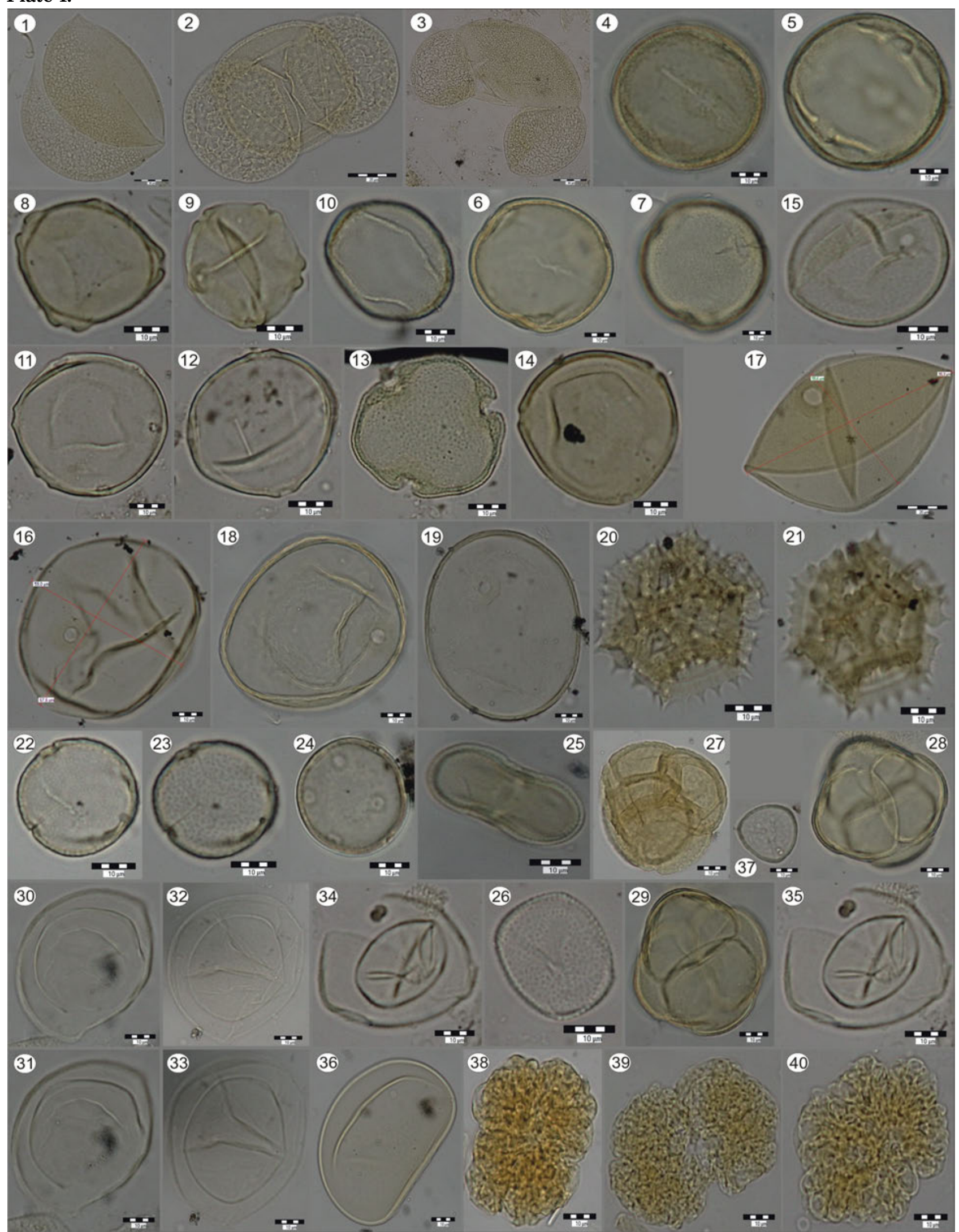


Table 2. Stratigraphy of the profile Prášilské Lake (Bohemian Forest, Czech Republic)

\begin{tabular}{|c|c|c|c|}
\hline Depth m & Years A.D. & Stratigraphy, L PAZ & L PAZ \\
\hline 0.01 & 1994 & & \\
\hline 0.02 & 1983 & PRI-6-Xb (depth 0-2 cm) & Picea-Pinus \\
\hline 0.03 & 1973 & & \\
\hline 0.04 & 1963 & & \\
\hline 0.05 & 1950 & & \\
\hline 0.06 & 1934 & PRI-5-Xb (depth 2-6 cm) & $\begin{array}{l}\text { Picea - Betula - Quercus - Poaceae } \\
\text { - Antropophyta }\end{array}$ \\
\hline 0.07 & 1914 & & \\
\hline 0.08 & 1898 & & \\
\hline 0.09 & 1887 & & \\
\hline 0.10 & 1866 & & \\
\hline 0.11 & 1843 & & \\
\hline 0.12 & 1825 & PRI-4-Xc (depth 6-12 cm) & Picea - Corylus - Antropophyta \\
\hline 0.13 & 1800 & & \\
\hline 0.14 & 1780 & & \\
\hline 0.15 & 1760 & & \\
\hline 0.17 & 1700 & & \\
\hline $0.19-0.25$ & & PRI-3-Xc (depth 12-25 cm) & $\begin{array}{l}\text { Picea - Fagus - Corylus - Juniperus } \\
\text { - Antropophyta - (Polypodiaceae) } \\
\end{array}$ \\
\hline $0.27-0.37$ & & PRI-2-Xb (depth 25-37 cm) & $\begin{array}{l}\text { Fagus - Picea - Abies - Antropophyta } \\
-(\text { Botryococcus })\end{array}$ \\
\hline $0.39-0.47$ & & PRI-1-Xb (depth 37-47 cm) & Fagus - Picea - Alnus \\
\hline
\end{tabular}

2. Forestation of the territory is much more favourable here in the Bohemian Forest than in the more negatively influenced and affected the Krušné hory Mts (Vile et al. 1995, Novák et al. 2008).

3. The lower part of the profile PRI-1 records the vegetation development only little affected by human. The human impact on the natural ecosystem has been recorded since the beginning of the zone PRI-2 of the Younger Subatlantic.

4. Changes in the sediment type as a light clayey layer in the depths of 0.01-0.02, 0.09-0.11, 0.19$0.21 \mathrm{~m}$ were probably caused by intensive erosion in the Prášilské Lake catchment. They were closely connected with the human activity. The character of forest growth changes, when the ratio of spruce and beech turns in favour of spruce (in $0.23 \mathrm{~m}$ ) and coniferous forests started to prevail in the Bohemian Forest. The modification is probably caused by climate change (windstorms, windfallen trees) and also by human impact (growth burning, beginnings of farming, preparation of fields and meadows, calamities caused by pests). Two younger changes in the depths of 0.01-0.02 and 0.09-0.11 $\mathrm{m}$ have been caused to the bigger extent by human intensive farming activity, which is proved by findings of pollen maize grains (Zea mays) falling into the years of 1934 and 1963 according to dating. Maize cultivation markedly supports soil erosion. These 3 clay layers occurring in the lake sediment drew attention to the change of vegetation, climate and human activity.

5. An important finding in sediments is microspores of quillwort (Isoëtes) in the depths of 0.41-0.47, 0.11-0.13 and 0.07-0.09 $\mathrm{m}$, even if they are sporadic they prove a theory that in the past

Plate I. Palynomorphs from the Prášilské Lake (PRI). - AP. 1) Picea, depth $0.10 \mathrm{~m}$. 2) Pinus depth $0.10 \mathrm{~m}$. 3) Abies, depth 0.47 m. 4-7) Fagus, depth 0.09 m. 8-9) Alnus, depth 0.10 m. 10) Quercus, depth 0.09 m. 11-12) Carpinus, depth 0.47 m. 13) Tilia, depth $0.47 \mathrm{~m}$. 14) Corylus, depth $0.10 \mathrm{~m}$. NAP. 15) Poaceae, depth $0.10 \mathrm{~m}$. 16-17) Zea mays, depth 0.06 m. 18) Cerealia T. Triticum, depth 0.4 m. 19) Cerealia T. Secale, depth 0.04 m. 20-21) Asteraceae Liguliflorae, depth 0.06 m. 22-23) Rumex t. alpinus, depth 0.14 m. 24) Plantago lanceolata, depth 0.04 m. 25) Apiaceae, depth 0.09 m. 26) Potamogeton, depth $0.47 \mathrm{~m} .27-29)$ Ericaceae, depth 0.06, 0.09 m. PTERIDOPHYTA. 30-35) Isoëtes, depth 0.09, 0.10, 0.47 m. 36) Polypodiaceae, depth $0.06 \mathrm{~m}$. BRYOPHYTA. 37) Sphagnum, depth $0.47 \mathrm{~m}$. ALGAE. 38-40) Botryococcus, depth $0.10 \mathrm{~m}$. Scale $30 \mu \mathrm{m}$ (3), $20 \mu \mathrm{m}$ (1-2, 16), $10 \mu \mathrm{m}$ (4-15, 17-40). Photo E. Břízová. 
they might have grown in most lakes in the Bohemian Forest (Břízová 2011). What might be a cause of its disappearance is not still clear. It might be the change of water $\mathrm{pH}$. They were found out in the zones, where an amount of green algae of g. Botryococcus in the sediment considerably declined.

\section{ACKNOWLEDGMENTS}

Within the grant project of J. Hruška (GA ČR No. 205/96/0933, ĆGS research programme) the upper part of the Prášilské Lake, $0.47 \mathrm{~m}$ thick, was palynologically evaluated some time ago for comparison with other methods determining humolite age and conditions of its origin. The author continued in dealing with this problems during the geological mapping of the National Park Šmava (Bohemian Forest) on scale of $1: 25000$ within the research aim of MZP 0002579801 and within the research aim of MZP Global Climatic Changes.

\section{REFERENCES}

Adamová, M., Novák, M. 1998. On the use of silver discs to extract ${ }^{210} \mathrm{~Pb}$ and ${ }^{208} \mathrm{Po}$ for radiogenic ${ }^{210} \mathrm{~Pb}$ dating of recent peat deposits. Challenges to Chemical Geology, Refereed Papers from MAEGS-10. Czech Geological Survey, Prague, 145-159.

Babůrek, J. 1996. Geological research of Bohemian Forest. Silva Gabreta, 1, 27-32.

Babůrek, J. 2001. Geologická stavba okolí Kašperských hor. Aktuality šumavského výzkumu, 11-14. Srní.

Babůrek, J., Pošmourný, K. 2001.Významné geologické lokality na území národního parku a chráněné krajinné oblasti Šumava (Important geological localities on the territory of the Šumava National Park and Protected Landscape Area). Silva Gabreta, 6, 27-34.

Babůrek, J., Břízová, E., Havlíček, P., Hrazdíra, P., Krupička, J., Mentlík, P., Petáková, Z., Skácelová, D., Śrámek, J., Žáček, V., Verner, K., Lysenko, V., Žák, J., 2006a. Vysvětlivky k základní geologické mapě České republiky 1:25 000, list 22-333 Srní. MS Česká geologická služba Praha, 75 s.

Babůrek, J., Pertoldová, J., Verner, K., Jiřička, J., 2006. Průvodce geologií Šumavy. Správa NP a CHKO Šumava Vimperk. $118 \mathrm{~s}$.
Beug, H. J. 2004. Leitfaden der Pollenbestimmung für Mitteleuropa und angrenzende Gebiete. Verlag Dr. Friedrich Pfeil. München.

Břízová, E. 1991a. Výsledky palynologického výzkumu v roce 1989 (The results of palynological research in 1989). Zpr. geol. Výzk. v Roce 1989, 27-29. Praha.

Břízová, E. 1991b. Výsledky pylových analýz $\mathrm{v}$ roce 1990 (The results of pollen analysis in 1990). Zpr. geol. Výzk. v Roce 1990, 20-21. Praha.

Bř́zová, E. 1993. The importance of pollen analysis for the reconstruction of vegetation development during the last two millenia. - In: Růžičková, E., Zeman, A., Mirecki, J. (eds.): Application of direct and indirect data for the reconstruction of climate during the last two millenia. Papers presented at the workshop of PAGES Stream I held in Brno, June1992, 22-29. Praha. Bř́zová, E. 1996. Palynological research in the Šumava Mountains (Palynologický výzkum Šumavy). Silva Gabreta, 1, 109-113.

Břízová, E. 2004. Palynologický výzkum rašelinište a jezer pro účely geologického mapování. - In: Dvořák, L., Šustr P. (eds.): Aktuality šumavského výzkumu II. Sbornik z konference 4.-7.10. v Srní, 164-171.

Břízová, E. 2007a. Palynological research of the Bohemian Forest mires and lakes as a subject of geomorphological and geological study. - In: Hradecký, J., Pánek, T. (eds.): Geomorfologický sborník 6 Stav geomorfologických výzkumü v roce 2007, 11. Ostravská univerzita v Ostravě.

Břízová, E. 2007b. Quillworts (Isoëtes) - significant glacial relict in the Quaternary lacustrine sediments of the Czech Republic. - In: Zlinská A. (ed.): 8. paleontologická konferencia, 22-23. Štátny geologický ústav Dionýza Štúra Bratislava.

Břízová, E. 2007c. Isoëtes - glacial relict in the Quaternary lake sediments of the Czech Republic. - In: Winter, H. (ed.): III Polska Konferncja Paleobotaniki Czwartorzedu. Paleośrodowiska $i$ zmiany roślinności terenów podgórskich $i$ polskich gór, 4-6. Państwowy Instytut Geologiczny Warszawa. Szklarska Poreba.

Břízová, E. 2007d. Quillworts (Isoëtes) - significant glacial relict in the Quaternary lake sediments of the Czech Republic. - In: Dašková, J., \& Kvaček, J. (eds.): Palaeobotany - contributions to the evolution of plants and vegetation, 14-17. National Muzeum Prague. 
Břízová, E. 2009. Quaternary environmental history of the Čejčské jezero (S. Moravia, Czech Republic). Bulletin of Geosciences, 84, 4, 637652, DOI 10.3140/bull.geosci.1140.

Břízová, E. 2011: Quillwort (Isoëtes) mysterious plant of our nature. Sborník Národního muzea $\checkmark$ Praze. Acta Musei Nationalis Pragae, series B - Historia Naturalis. 67 (1-2), 25-34. Prague.

Břízová, E. 2012. Reconstruction of vegetation and human impact from the sediments of the Rybárenská Slat mire (Bohemian Forest, Czech Republic). Silva Gabreta 18, 2, 61-78. Vimperk.

Břízová, E., Havlíček, P. 2004. Nový výzkum rašelinišť na Šumavě (New research of the peat bogs in the Bohemian/Bavarian Forest /Šumava Mts./). Zpr. geol. Výzk. v Roce 2003, 55-57. Praha.

Břízová, E., Havlíček, P., Mentlík, P. 2006. Geologický, geomorfologický a paleoekologický výzkum sedimentů v okolí Srní (Geological, geomorphological and palaeoecological research of the sediments in the Srní area). Zpr. geol. Výzk. v Roce 2005, 62-64. Praha.

Břízová E., Juřičková L. 2011. Could canopy forests survive agricultural colonization in the Polabí lowland (Czech Republic)? Bulletin of Geosciences 86, 2, 283-300. ISSN 1214-1119. DOI 10.3140/bull.geosci.1260.

Břízová, E., Mentlík, P. 2005a. Za tajemstvím Staré jímky na Prášilsku. Šumava, 11, jaro 2005, 18-19. Vimperk.

Břízová, E., Mentlík, P. 2005b. Preliminary results of geomorphological research and pollen analysis in the Stará jímka area (the Bohemian Forest). - In: Rypl, J. (ed.): Geomorfologický sbornik 4. Stav geomorfologických výzkumů $v$ roce 2005 . Př́spěvky z mezinárodního semináře Geomorfologie 05, Nové Hrady. 155-158. České Budějovice.

Břízová, E., Pazdur, A. 2007. Změny přírodního prostředí ve Staré jímce (rašeliniště - jezero) v průběhu posledních 15000 let. - In: Dvořák, L., Šustr, P., Braun, V., (eds.): Aktuality šumavského výzkumu III., 39-43. Správa NP a CHKO Šumava. Vimperk.

Břízová, E., Pazdur, A., Piotrowska, N. 2012. Upper Holocene development of vegetation and radiocarbon dating in the vicinity of the Cerhovka brook (Bohemian-Moravian Uplands, Czech Republic). Geochronometria 39, 4, 251-262. DOI 10.2478/s13386-012-0016-2.
Erdtman, G. 1943. An introduction to pollen analysis. New York.

Erdtman, G. 1954. An introduction to pollen analysis. Waltham (USA).

Faegri, K. et al. 1964: Textbook of pollen-analysis. Copenhagen.

Firbas, F., 1949, 1952. Spät- und nacheiszeitliche Waldgeschichte Mitteleuropas nördlich der Alpen. I. Allgemeine Waldgeschichte. II. Waldgeschichte der einzelnen Landschaften. Jena.

Hruška, J., Charles, D. F., Břízová, E., Veselý, J., Novák, M., Kopáček, J. (1999): Paleolimnologická rekonstrukce preindustriálních acidobazických vlastností povrchových vod postižených antropogenní acidifikací. MS Závěrečná zpráva grantového projektu GAČR 205/96/0933.

Jankovská, V., 2006. Late Glacial and Holocene history of Plešné Lake and its surrounding landscape based on pollen and palaeoalgological analyses. Biologia, 61, 20, 371-385. Bratislava.

Kopáček, J., Vrba, J., Šantrůčková, H. eds. 2006. Catchment-lake ecosystems in the Bohemian Forest (Central Europe): An integrated ecological research. Biologia, 61, 20, 363-542.

Kubát, K., Hrouda, L., Chrtek, J. jun., Kaplan, Z., Kirschner, J., Štěpánek, J. eds. 2002. Klíč ke květeně České republiky (Key to flora of the Czech Republic). Academia Praha, 928 s.

Mangerud, J., Andersen, S. T., Berglund, B. E., Conner, J. J. 1974. Quaternary stratigraphy of Norden, a propsal for terminology and classification. Boreas, 3, 3, 109-128.

Mentlík, P. 2002. Příspěvek ke geomorfologii okolí Prášilského jezera (povodí Jezerního potoka). Silva Gabreta 8, 19-42.

Mentlík, P. 2003. Mapování glaciálních forem georeliéfu v okolí Prášilského jezera na Šumavě (The geomorphological mapping of the glacial forms in the Prášilské Lake area). - In: Mentlík, P. (ed.). Geomorfologický sborník 2, 155-164.

Mentlík, P., Břízová, E. 2005. O stáří sedimentů Staré jímky. Šumava, 11, podzim 2005,18-19. Vimperk.

Mentlík, P., Lisá, L., Břízová, E. 2006. Předběžné výsledky interdisciplinárního výzkumu zalednění v okolí Prášilského jezera. - In: Létal, A., Smolová, I. (eds.): Geomorfologický sborník 5, Stav geomorfologických výzkumů v roce 2006 , 45. Olomouc.

Mentlík, P., Minár, J., Břízová, E., Lisá, L., Tábořík P., Stacke, V., 2010. Glaciation in the 
surroundings of Prášilské Lake (Bohemian Forest, Czech Republic). Geomorphology, 117, 1-2, 181-194. ISSN 0169-555X. DOI 10.1016/ j.geomorph.2009.12.001.

Nalepka, D., Walanus, A. 2003. Data processing in pollen analysis. Acta Palaeobotanica, 43, 1, 125.

Novák, M., Břízová, E., Adamová, M., Erbanová, L., Bottrell, S.H., 2008. Accumulation of organic carbon over the past 150 years in five freshwater peatlands in western and central Europe. Science of the Total Environment 390, 2-3, 425436.

Nožička, J. 1957. Přehled vývoje našich lesů. SZN Praha.

Overbeck, F. 1958. Pollenanalyse quartärer Bildungen. - In: Freund, H. et al.: Handbuch der Mikroskopie in der Technik. Frankfurt/Main, 325-410.

Reissinger, A., 1930. Untersuchungen über den Niedersonthofener See im bayrischen Allgäu. Wiss. Veröff. Dtsch. u. Österr. Alpenvereins, 6.

Reissinger, A., 1933. Schlammuntersuchungen am Schwarzen See im Böhmerwald. Ber. D. Naturw. Ges., 3, 1-6. Bayreuth.

Řeháková, Z. 1991. Předběžná zpráva o studiu diatom Černého jezera na Šumavě (The preliminary report on the study of diatoms of Černé jezero Lake in Šumava). Zpr. geol. Výzk. v Roce 1990, 131-133. Praha.

Spitzer, K., Bufková, I. 2008. Šumavská rašeliniště. Správa NP a CHKO Šumava. Vimperk. 203 s.

Svitavská-Svobodová, H., Frantík, T., Wild, J., Melichar, V. 2007. Pylový monitoring Šumavy (Pollen monitoring of the Bohemian Forest in the years 1996-2006). - In: Dvořák, L., Šustr P., Braun, V. (eds.): Aktuality šumavského výzkumu III., 36-38. Vimperk.

Šantrůčková, H., Vrba, J., Křenová, Z., Svoboda, M., Benčoková, A., Edwards, M., Fuchs, R., Hais, R., Hruška, J., Kopáček, J., Matějka, K., Rusek J. 2010. Co vyprávěji šumavské smrčiny. Správa NP a CHKO Šumava. Vimperk. $153 \mathrm{~s}$.

Veselý, J. 1994. Investigation of the nature of the Šumava Lakes: a review. Čas. Nár. Muz., 163/14, 103-120. Praha.

Veselý, J., Almquist-Jacobson, H., Miller, L. M., Norton, S. A., Appleby, P., Dixit, A. S., Smol, J. P. 1993. The history and impact of air pollution at Čertovo lake, southwestern Czech Republic. Journal of Paleolimnology, 8, 211-231. Belgium.

Vile, M.A., Novák, M.J.V., Břízová, E., Wieder, R.K., Schell, W.R. 1995. Historical rates of atmospheric metal deposition using ${ }^{210} \mathrm{~Pb}$ dates Sphagnum peat cores: corroboration, computation, and interpretation. Water, Air and Soil Pollution, 79, (1-4), 89-106. The Netherlands.

Vočadlová, K., Kř́žek, M., Čtvrtlíková, M., Hekera, P., 2007. Hypothesis for the last stage of glaciation in the Černé Lake area (Bohemian Forest, Czech Republic). Silva Gabreta, 13, 3, 205-216. Vimperk.

Walanus, A., Nalepka, D. 1999. POLPAL. Program for counting pollen grains, diagrams plotting and numerical analysis. Acta Paleobot., Suppl. 2, 659-661. Kraków.

Walanus, A., Nalepka, D. 2010. Calibration of Mangerud's boundaries. Radiocarbon 52,4, 1639-1644. 